\title{
Effects of Psychological and Demographic Factors on Academic Performance
}

\section{Psikolojik ve Demografik Etkilerin Akademik Performans Üzerindeki Etkileri}

\author{
Rabia ÇizEL* \\ Beykan ÇIZZL * \\ Edina AJANOVIC ${ }^{* * *}$
}

\begin{abstract}
Academic performance is a highly important topic for directing one's future. In examining academic performance it is important to measure the effectiveness of various factors on this issue. In this study, the effects of psychological factors such as personality traits and attachment style on academic performance will be examined. In addition, the effect of a demographic variable such as gender was tested in the model as a categorical variable. Research results showed the significant effect of personality traits such as extraversion and openness, together with secure attachment style, in predicting academic performance. In addition, the gender variable showed a significant effect in the evaluation of students' academic performance as high or low. The results of this study are interpreted and discussed within the available literature in the field. The results of this study offer insight into how psychological factors such as personality traits and attachment styles can affect academic performance.
\end{abstract}

Keywords: Academic Performance, Gender, Personality, Attachment Style, Extraversion, Openness

$\ddot{O}_{z}$ : Akademik performans, bireylerin geleceklerini yönlendirmeleri açısından son derece önemli bir konudur. Akademik performans üzerinde etkili olan çeşitli faktörlerin incelenmesi akademik performansın değerlendirilmesi açısından önem arz etmektedir. Bu çalışmada, kişilik özellikleri ve bağlanma tarzları gibi psikolojik faktörlerin üniversite öğrencilerinin akademik başarıları üzerindeki etkisi incelenmektedir. Bununla birlikte, demografik değişkenlerden cinsiyetin etkisi de model içerisinde kategorik değişken olarak test edilmiştir. Araştırma bulguları, kişilik tiplerinden dişa dönüklük ve deneyime açıklı̆̆ın ve bağlanma tarzlarından güvenli bağlanmanın akademik performansın tahmin edilmesinde anlamlı etkiye sahip olduğunu ortaya koymaktadır. Ayrıca, cinsiyet değişkenin de öğrencilerin akademik performansının düşük ve yüksek olarak değerlendirilmesinde anlamlı bir etkiye sahip olduğu saptanmıştır. Araştırma bulguları ilgili yazın desteği ile tartışılmış ve yorumlanmıştır. Araştırma sonuçlarının üniversite öğrencilerin akademik başarısının değerlendirilmesinde kişilik özellikleri ve bağlanma tarzları gibi önemli psikolojik değişkenlerin etkisini göstermesi açısından önemli olabileceği düşünülmektedir.

Anahtar sözcükler: Akademik Performans, Cinsiyet, Kişilik, Ruhbilim, Dışa Dönüklük, Deneyime Açıklık

\footnotetext{
* Doç. Dr., Akdeniz Üniversitesi, IIBF ÇEEİ Bölümü, Antalya. rabiacizel@akdeniz.edu.tr

** Prof. Dr., Akdeniz Üniversitesi, Turizm Fakültesi, Antalya. beykan@akdeniz.edu.tr

**** Lect., Akdeniz Üniversitesi, Turizm Fakültesi, Antalya. edinaajanovic@ akdeniz.edu.tr
} 


\section{Introduction}

The number of studies concerning academic performance in terms of learning levels and individual differences has recently increased. Recent studies show the importance of personality and cognitive intelligence as variables in predicting potential success in the given assignment. Over the last twenty years educational researchers have emphasized there is a large number of internal and external factors affecting students' academic performance. While some researchers have examined the relationship between motivation and academic success (Zhou 2015), others have tested the correlation between personality traits and academic performance. Studies on personality traits date from the 1930's when Gordon Allport and others began with 18000 terms to define differences between individuals. These results showed how complex the concept of personality is and indicated the necessity to work further on it as individual personal traits directly affect one's working performance.

Bowlby's attachment theory, proposes that the attachment styles in adulthood will be affected by the form of attachment that babies develop with first-degree caregivers like parents, babysitters etc. Research results show that a secure attachment style positively affects romantic relationships. Although there are only a few studies that examine the relationship between attachment styles and academic performance, these studies show that these are effective in defining academic performance.

The aim of this study was to test whether a model of personality traits, attachment styles and gender could be effective in the prediction of academic performance. The hypothesis derived from literature review was analyzed through logistic regression. The results showed the significant effect in predicting academic performance of personality traits such as extraversion, openness to experience and secure attachment style. In addition, the gender variable showed a significant effect in the evaluation of students' academic performance as high or low.

\section{Literature Review}

Attachment theory involves evolutionary, developmental, and cognitive processes (such as attention and regulation) forming an interconnected explanatory model of close relationships. According to this theory, individual differences (thoughts, emotions and expectations) are shown (Simpson \& Rholes 2015) in the scope of a relational approach known as attachment style (Ainsworth et. al. 1978) which shapes the individual's perception of oneself, of others and of relationships. The theory of attachment is conceptualized as the tendency of people to develop strong love relations with others. This bond which is of great importance for children's development, allows them to overcome fears and troubles, providing them with the possibility to safely discover themselves within their physical and social environment.

Attachment styles are considered as holistic system of interaction with each other in order to produce behavioral patterns. Patterns determine one's interpersonal experiences. Attachment styles are important premises for quality interpersonal relations and psychological well-being. Bowlby (1973) sees attachment as a primary necessity and an important factor in personality development, which cannot be derived from someone else. In order to analyze the relationship between children and their caregivers in one experiment, Ainsworth et al. (1978) separated babies from their mothers/sitters and categorized them according to their behavioral patterns shown after they were brought back together. According to this experiment, three different attachment styles were derived described as: secure, avoidance and anxious. Hazan and Shaver (1987) managed to follow these three attachment types in relationships between adults. One individual's normal or abnormal characteristics were deeply affected by the attachment forms. 
According to the results of related studies, sincerity, trust and independence are typical of a secure attachment style. On the other hand, insecure attachment is accompanied by a lack of self-confidence, fear of sincerity, lack of trust, and dependence (Hazan \& Shaver 1987). Children who established secure and supportive relationship with their mothers in childhood have more confidence in themselves and others, while also showing the ability to positively solve the problems they face in their future life.

Initial studies on the attachment styles among adults are based on Ainsworth's taxonomy. According to this taxonomy, individuals are presented with three basic attachment patterns and asked to define which one of these can best characterize them (Hazan \& Shaver 1987). Although there are different approaches in measuring these dimensions in the literature, many researchers use this typology when defining attachment styles. Research studies examining attachment among adults were focused on romantic relationships as an alternative context for the attachment behavioral system. In this relationship, there were functional similarities between individual's relationship with their partner and the relationship between baby and parent (Shaver, Hazan \& Bradshaw 1988). Those individuals with an anxious attachment style were more concerned in their answers, regarding how suitable their partner is for them. Individuals with avoiding attachment type, said they do not like it when someone opens emotionally to them and to be supported by others. Apart from being reliable, individuals with a secure attachment style are more willing to show intimacy and offer their support when needed. Anxious individuals have a tendency to show more reaction towards negative emotions, while avoiding individuals had problems in escaping from negative emotions (Gillath et al. 2005). Anxious and avoiding attachment styles were conceptualized as being insecure attachment styles.

\section{Relationship between Attachment Styles and Performance}

In a study conducted in Denmark, it was discovered that interactive communication established between teacher and student had a positive effect on children's academic success (Gupta \& Simonsen 2016). These teachers had a high level of education focused on pedagogy. 2-year old children reached high levels in language learning and mathematics. When they arrived at the age of 16, it was shown that the children enrolled in a center-based child care home had higher academic achievement. In their study among high school students, Tavakolizadeh et al. (2015) found a statistically significant relationship between a secure attachment style and academic self-sufficiency and between a secure attachment and meta-cognitive skills.

In a set of studies conducted by Gillath and his colleagues (Edelstein \& Gillath 2008; Gillath et al. 2009) it was found that individuals with an avoiding attachment style achieve higher performance with tasks that require attention. Avoiding individuals show a better performance because they have the ability to suppress the distracters around their task or can ignore the parasites and, compared to their non-avoiding peers, they can focus better on their task. On the contrary, anxious attachment style individuals are associated with high sensitivity and have a lower ability to move away from distractions. Although performance on general cognitive tasks cannot be predicted for anxious attached individuals, they still tend to show cognitive bias in those tasks involving stress, threats or relational material (Mikulincer, Gillath \& Shaver 2002). In such assignments, it is highly likely that those who are anxiously attached will be more occupied with negative emotions and thoughts about rejection and abandonment and have a higher chances of being overwhelmed by emotional floods or negative feelings and emotions. In their study when attachment styles were examined as determinants of driving performance, Gillath et al. (2017) found that drivers with an anxious attachment style tend to 
exhibit more risky behavior (such as driving errors, lane violations). On the other hand, individuals with an avoiding attachment style it was found, have accidents caused through the driver's fault and with serious consequences. The explanation for this may be due to the fact that avoiding individuals are less interested in others.

Harms (2011) described how the topic of attachment styles was examined in organizations, particularly in terms of organizational behavior and performance, and which gaps could be filled in future work. Fletcher and his colleagues (2016) found that trainee doctors with a low-level of avoidance and of anxious attachment, performed better in communication with patients and in their clinical skills.

In the study of Maltais and others (2015), the mediating role of perceived academic competence and symptoms of anxiety in relations between safe attachment to mothers and goal achievement among first-year-middle-school students was detected. Results showed that there is the mediating role of perceived academic performance in the relation between a secure attachment style and orientation towards mastery goals. Children with a safe internal working model, view themselves as worthy of compassion and respect and also in moments of stress see others as reliable, accessible and responsive. This encourages trustworthy, curious and autonomous research and allows the development of cognitive skills (attention, working memory and planning) and competencies for effective problem solving. On the contrary, children with an unsecured inner working model are thinking that other people do not like or want them. These negative cognitive schemes lead them to states of feeling nervous while discovering, developing self-protection strategies and having emotional problems. The results of many studies (Jacobsen et al. 1994; Learner \& Kruger 1997; Jacobsen \& Hoffman 1997; Moss \& St-Laurent 2001; Duchesne \& Larose 2007) have shown that children and adults with a secure attachment style achieve a higher academic performance when compared to children and adults with other attachment styles.

A secure attachment style, which is characterized by positive psychological power, contributes to working performance and allows employees to work as autonomously as they can with colleagues. When examining relations between a secure attachment style and working performance, Hazan and Shaver (1990) proved that people with this type of attachment style have a higher level of satisfaction in interpersonal relations with colleagues, work security, income, promotion activities and generally, have more positive attitudes on various topics. These people are less prone to postpone their tasks, to have problems with their finalization or business failure of their colleagues or of possibilities to be rejected. On the other hand, those with an insecure attachment style, emphasized the existence of worries regarding interference with their performance, dissatisfaction with colleagues, having problems in finalizing their projects, being disliked by their peers and managers and not receiving the incentives they desire. Hazan and Shaver (1990), state that an insecure attachment style will significantly disrupt working performance.

Mikulciner and Shaver (2007) claim that a secure attachment style will enhance work performance because people feel they can cope with difficulties by relying on the support of others when needed. They emphasize that secure attachment individuals tend to trust others and that they are not easily disturbed by concerns about their relationship, making them work more effectively and efficiently. After fifteen months of evaluating attachment styles, Ronen and Zuroff (2017) found that employees with a secure attachment style had a better chance of showing higher job performance compared to more insecure employees. In their study, where the relationship between the attachment style of secondary students and academic performance 
was examined, McCormick et.al. 2016 found that children with an insecure attachment style were scoring lower at reading and mathematics skills, while an average score was detected amongst those with an anxious attachment style.

\section{Relations between Personality Traits and Performance}

Personality is the entirety of patterns of behavior that distinguish one individual from the other; in other words it represents all the mental, emotional and physical reactions that guide an individual's life (Burger 2006). Personality is the sum of the characteristics which an individual has from birth and develops within society. The most important factor that distinguishes people from each other is personality. Personality is the structure of relationships that one develops in a unique manner, either on its own, or in interaction with his/her environment. The complexity of the concept of personality led to the emergence of a wide range of personality theories. Common aspects of these different personality theories are: they make a short and clear statement of complex behaviors, combine existing information into a meaningful whole leading to the formation of new facts, opinions and information, encourage future research and provide space for making predictions. Research of personality through five dimensions started in the 1960's and gained momentum in the 1990's, resulting in numerous studies on this topic. The view that most of the personality characteristic approaches can be gathered under the "five factors" became commonly accepted. This five-dimensional approach is called the "Big Five" (McCrae \& Costa 1985; 2008; Friedman \& Schustack 1999).

The extraversion dimension; reflects characteristics such as being social, assertiveness, defending one's rights and opinion, being active and talkative. Extraverted individuals are active, sympathetic, enthusiastic and more inclined to self-disclosure behaviours (McCrae \& Costa 1985). The agreeableness dimension defines individuals who have a friendly approach to others, collaborative, trustworthy, warm, humble, supportive, and emotionally close to others (McCrae \& John 1992). The third dimension, conscientiousness, refers to an individual who is careful, attentive, meticulous, responsible, regular, planned, success oriented, hardworking and persistent. The neuroticism dimension describes anxious, depressed, nervous, bored, emotional and sad individuals unable to trust the others. Finally the last dimension, openness, is the hardest one to be defined, as this person should be known for a strong imagination, culture, knowledge and curiosity about learning, originality, open-mind, intelligence and artist-sensitivity (Barrick \& Mount 1991). When reviewing the literature one finds extensive research studies which tested the relationship between these five personality traits and variables such as happiness, robustness, emotional intelligence, life satisfaction, stress coping strategies, self-confidence and demographics (Özer 2013).

The dominance of the Five Factor Personality Theory in the personality field, led to a number of studies that investigated the relationship between attachment styles and the Big Five Personality Traits. In one of the first studies of this kind, Shaver and Brennan (1992) found the relationship between a secure attachment style, extraversion, agreeableness and neuroticism. It was found that an anxious attachment was closely related to neuroticism while an avoiding attachment correlated with incompatibility, introversion and emotional instability. In Noftle and Shaver's (2006) study it was shown that there is a significant relationship between an anxious attachment and emotional instability and a slightly negative correlation between an avoiding style and extraversion and conscientiousness. The study of Roisman et al. (2007) emphasized a moderate relationship between an anxious attachment and emotional imbalance and noncompliance. In addition, avoidance was related to the decrease in extraversion. Similarly, in other studies (Picardi et al. 2005; Gillath et al. 2008) there was no significant correlation found 
between an avoiding style and the Big Five, while an emotional instability and an anxious attachment style were significantly related.

There is a common idea amongst researchers in psychology and organizational psychology regarding the existence of a relationship between performance and educational success. Personality traits are influential on the individual's cognitive abilities, motivation and capabilities. In their research conducted on army members, Conte et al. (2017) found significant associations between job performance and personality dimensions proposed by the Big Five theory. Blanch and Aluja (2013) found significant relations between a high school student's personality traits and academic success (language competence and mathematics).

In his study of the influence of academic competencies, cognitive ability and personality on academic performance, Bonaccio et al. (2016) found that this performance is significantly related to an agreeableness personality dimension. Wihler et al.'s (2017) study proved that there is significant relation between an extravert personality and nurses' working performance. Communication was proven to have a mediating effect between personality traits and team performance (Macht \& Nembhard 2015). In a study of the academic achievement of 249 elementary school students in China, it was shown that apart from neuroticism, all the other five personality traits and self-assessment motivation influence academic performance (Zhou 2015).

Recent meta-analysis show conscientiousness personality traits had the strongest correlation with academic performance (Richardson et al. 2012). Conscientious students tend to make plans, behave according to them and make effort towards their realization. As a result, they can show better performance in school (Caprara et al. 2011). On the other hand, variable relations were found between academic performance and openness to experiences, conscientiousness, neuroticism and extraversion. Poropat (2014) investigated the relationship between academic performance and personality traits in his meta-analytic study, and found that performance is related to all dimensions of the Big Five theory. Ciorbea and Pasarica (2013) found significant relationships between academic success and traits such as neuroticism, extraversion and psychotism in their research amongst university students.

According to the results of studies examining the relationship between the academic performance and the personality traits of students studying in different academic departments of universities (Vedel et al. 2015), psychology and arts/humanities students had high scores in terms of agreeableness and neuroticism, while economics students had low scores in these two dimensions. Psychology and arts/humanities students had low scores in the conscientiousness dimension. On the other hand the extraversion dimension showed higher scores with students of economics than those of natural sciences. In addition, psychology and art humanities department students scored high on openness towards development. According to the research results in studies among different cultures, it was concluded that the characteristics of neuroticism, extraversion, agreeableness and conscientiousness were higher amongst women than men.

In the study by Kim et al. (2017) of university students, it was found there was a positive correlation between total average note and conscientiousness dimension, while with openness there was negative one. While in some of the studies a positive correlation was detected between conscientiousness and academic success, there was also negative one between extraversion and academic successes. In few other studies a significant positive correlation was found between academic success and agreeableness, while this performance was being negatively influenced by the neuroticism. When combining results from all the previous studies reviewed in this paper, it can be concluded that the dimensions of conscientiousness and agreeableness are significantly correlated with academic success (Soric et al. 2017). Soric et al. (2017) found that 
conscientiousness among students is the best predictor of their academic success.

\section{Method}

The aim of this research is to test whether the personality traits, attachment styles and demographic characteristics of university students can be used to predict academic performance with a model. This research survey with random sample was conducted amongst 238 students from the Labor Economic department of the Faculty of Economics at Akdeniz University in Antalya, Turkey. Of the 238 participants, 142 were female, 96 were male students. The hypotheses tested in the research model for the purpose of the study were as follows:

H1: Personality traits have a meaningful effect on the evaluation of students' academic performance as high or low.

H1a. Extraversion has a meaningful effect on the evaluation of students' academic performance as high or low.

H1b. Agreeableness has a meaningful effect on the evaluation of students' academic performance as high or low.

H1c. Conscientiousness has a meaningful effect on evaluation of students' academic performance as high or low.

H1d. Neuroticism has a meaningful effect on evaluation of students' academic performance as high or low.

H1e. Openness has a meaningful effect on the evaluation of students' academic performance as high or low.

$\mathrm{H} 2$ : Attachment styles have a meaningful effect on the evaluation of students' academic performance as high or low.

H2a. Secure attachment style has a meaningful effect on the evaluation of students' academic performance as high or low.

H2b. Fearful attachment style has a meaningful effect on the evaluation of students' academic performance as high or low.

H2c. Preoccupied attachment style has a meaningful effect on the evaluation of students' academic performance as high or low.

H2d. Dismissing attachment style has a meaningful effect on the evaluation of students' academic performance as high or low.

H3: Gender has a meaningful effect on the evaluation of students' academic performance as high or low.

\section{Measurement Scale}

The questionnaire applied in this study consisted of personality traits inventory, relationship scale (attachment styles) and demographic questions. The Relationship Scale was used in this questionnaire in order to determine the attachment styles of the participants. It was determined that this scale developed by Griffin and Bartholomew (1994) and adapted to a Turkish version by Sumer and Güngör (1999), can be considered a valid and reliable measurement tool. Thirty items of measurement were gathered in 4 sub-dimensions, such as: secure, fearful, preoccupied and dismissing style. The Five Factor Personality Inventory, developed to measure the personality traits, consisted of 44 items on the self-assessment scale (John et al., 1991). Participants evaluated the extent to which each adjective reflects themselves on a 5-point Likert- 
type scale. Five Factor Personality Inventory was translated into Turkish by Alkan (2007). The studies have shown that the Turkish scale is similar to the original scale and has similar subdimensions and can be considered a valid and reliable measurement tool (Sumer, Lajunen \& Özkan 2005; Alkan 2007). The items of this measurement are gathered under the five dimensions: extraversion, agreeableness, conscientiousness, neuroticism and openness toward development. The general average academic note was used to evaluate the academic performance of the students.

First, validity and reliability analyzes was conducted for the personality scale. For a reliability indicator of internal validity Cronbach Alpha was employed, while confirmatory factor analysis was determined for construct validity. Values for each of these dimensions are given in Table 1. All calculated values were accepted above the limit of 0.70 (Nunnally 1978).

Table 1. Reliability Test Results for Personality Scale

\begin{tabular}{|l|c|}
\hline Factors & Cronbach's Alpha Values \\
\hline Extraversion & 0,73 \\
\hline Agreeableness & 0,74 \\
\hline Conscientiousness & 0,79 \\
\hline Neuroticism & 0,80 \\
\hline Openness & 0,71 \\
\hline
\end{tabular}

For construct validity the Five Factor scale was tested based upon confirmatory analysis. The confirmatory factor analysis showed that the scale is compatible with 44 items and 5 subdimensions. When examining compliance indexes of the measurement model (Table 2), it can be said that all items included in the model are compatible with it. These finds show that statements are clearly defined by the factors and that these can be regarded as proof of the structural validity of the scale.

Table 2. Compliance Indexes for Personality Measurement Model

\begin{tabular}{|l|l|l|l|l|l|l|l|l|}
\hline Model & $\boldsymbol{\chi} \mathbf{2}$ & $\boldsymbol{\chi 2} / \mathbf{s d}$ & RMSEA & GFI & AGFI & CFI & TLI & NFI \\
\hline & 680,57 & 2,60 & 0,061 & 0,93 & 0,91 & 0,90 & 0,91 & 0,91 \\
\hline
\end{tabular}

In a similar manner the validity and reliability analysis for the attachment style scale were conducted. For the scale reliability indicator of internal validity Cronbach Alpha was calculated. Values for each attachment style dimensions are given in Table 3. All calculated values were accepted above the limit of 0.70 (Nunnally 1978).

Table 3. Reliability Test Results for Relationship Scale

\begin{tabular}{|l|c|}
\hline Factors & Cronbach's Alpha Values \\
\hline Secure & 0,85 \\
\hline Fearful & 0,80 \\
\hline Preoccupied & 0,84 \\
\hline Dismissing & 0,81 \\
\hline
\end{tabular}

Confirmatory analysis was used in the assessment of construct validity for four factor scale and proved that 30 items and 2 sub-dimensions are compliant. By examining the compliance indexes of the measurement model, it can be said that all the items included in the model are compatible with it (Table 4).These results showed that the statements were explained by the factors and are 
proof of the structure validity of the measurement scale.

Table 4. Compliance Indexes for the Relationship Scale Measurement Model

\begin{tabular}{|l|l|l|l|l|l|l|l|l|}
\hline Model & $\boldsymbol{\chi} \mathbf{2}$ & $\boldsymbol{\chi} \mathbf{2} / \mathbf{s d}$ & RMSEA & GFI & AGFI & CFI & TLI & NFI \\
\hline & 804,57 & 2,85 & 0,057 & 0,92 & 0,90 & 0,91 & 0,90 & 0,91 \\
\hline
\end{tabular}

\section{Analysis Results}

In the study conducted with 238 participants, it was determined that there were no missing values and analyzes were carried out on a total of 238 questionnaires. Gender was taken as a categorical variable. Logistic regression was used to test the proposed hypothesis. Before incorporating independent variables into logistic regression analysis, the student's general academic average notes were classified into two groups: above 2.50 as high and below 2.50 , as low academic performance. In total, 114 students had low academic success while 124 students were classified as in the high academic performance group (Table 5).

Table 5. Initial Classification Results

\begin{tabular}{|l|c|c|c|}
\hline & \multicolumn{3}{|c|}{ Academic Performance } \\
\hline & Low (0) & High (1) & Accurate Classification (\%) \\
\hline Low (0) & 0 & 114 & 0,00 \\
\hline High (1) & 1 & 124 & 100,00 \\
\hline Total classification & 238 & 0 & 52,10 \\
\hline
\end{tabular}

According to the result obtained, it was determined that the correct classification rate of the program was $52.10 \%$ before the analysis. In the next step, in order to examine the effect of the predicting variable in the initial block obtained variables significance values, the load values at the determined degree of freedom are given in Table 6.

Table 6. Analysis Results for the Initial Model

\begin{tabular}{|l|l|l|c|c|c|}
\hline & & Scores & df & p \\
\hline Step 0 & Variables & Gender & $\mathbf{2 0 , 2 5 8}$ & $\mathbf{1}$ & $\mathbf{, 0 0 0}$ \\
\hline & Secure & $\mathbf{5 8 , 5 7 6}$ & $\mathbf{1}$ & $\mathbf{, 0 0 0}$ \\
\hline & Fearful &, 320 & 1 &, 571 \\
\hline & Preoccupied &, 106 & 1 &, 745 \\
\hline & Dismissing & 1,673 & 1 &, 196 \\
\hline & Extraversion & $\mathbf{4 7 , 6 3 0}$ & $\mathbf{1}$ & $\mathbf{, 0 0 0}$ \\
\hline & Agreeableness & 2,707 & 1 &, 100 \\
\hline & Conscientiousness &, 347 & 1 &, 556 \\
\hline & Neuroticism & $\mathbf{4 , 5 8 8}$ & $\mathbf{1}$ & $\mathbf{, 0 3 2}$ \\
\hline & Openness & $\mathbf{6 , 0 9 9}$ & $\mathbf{1}$ & $\mathbf{, 0 1 4}$ \\
\hline & & $\mathbf{8 6 , 0 5 3}$ & $\mathbf{1 0}$ & $\mathbf{, 0 0 0}$ \\
\hline
\end{tabular}

In examining Table 6 it can be seen that variables with significant influence at the initial model are secure attachment, among other students' attachment styles, and from personality traits extraversion, neuroticism and openness. Besides these, from demographic characteristics gender was shown to have significant influence in the initial model $(p<.05)$. In addition, it is seen that the model established with the variables covered in the study is meaningful as a whole $(p=$ 
$.000)$. After this stage what needed to be done was to define how each of the variables influence, and to what extent, when predicting variables, when included in the model. In Table 7 we present the analysis results about how well the model worked in the second step when independent variables are included in the model (Block 1).

Table 7. Omnibus Test of Model Coefficients

\begin{tabular}{|l|l|l|l|l|}
\hline & & Chi-square & Df & Sig. \\
\hline \multirow{2}{*}{ Step 1 } & Step & 59,83 & 16 &, 000 \\
\cline { 2 - 5 } & Block & 59,83 & 16 &, 000 \\
\cline { 2 - 5 } & Model & 59,83 & 16 &, 000 \\
\hline
\end{tabular}

As a result of the Omnibus test given in table 7 it was determined that the model obtained after the inclusion of the predictor variables with the initial model obtained without adding any variables was statistically significant $\left(\chi^{2}=15,11 \mathrm{df}=8 \mathrm{p}<.057\right)$. According to these values, also known as the model adaptation index, the model for estimating the academic performance proposed by the researchers seems to have a good fit (Pallant 2005). The values of "The Cox \& Snall $R$ Square" and "Nagelkerke $R$ Square" from the R2 statistics showing how much the variance dependent on the model is explained by the independent variables are shown in Table 8 .

Table 8. Model Explanatory Rates by Predictive Variables

\begin{tabular}{|l|l|l|l|}
\hline Step & -2 Log likelihood & Cox \& Snell R Square & Nagelkerke R Square \\
\hline 1 & $239,314^{(\mathrm{a})}$ &, 364 &, 486 \\
\hline
\end{tabular}

${ }^{\mathrm{a}}$ Estimation terminated at iteration number 5 because maximum iterations has been reached.

According to the The Cox \& Snall $R^{2}$ value, the dependent variable is defined as 0,364 by the predicting variables. Accordingly, 36,40\% of the academic performance is explained by the variables covered in the study. In addition, according to the value of Nagelkerke $\mathrm{R}^{2}$, which is a statistic that shows the ratio of variance explained, the ratio of the dependent variable to the predicted variable is 0.486 . According to this finding, $48.60 \%$ of academic performance is explained by the variables covered in the study. As a result of the Hosmer and Leme show test of whether the model is a reliable one, the $\chi^{2}$ value of 8 degrees of freedom is determined as 15,11 and because this value is higher than the critical one $(\mathrm{p}<.057)$ it can be concluded that model does not show incompatibility. In another words, the proposed model was supported by data covered in the study. Since logistic regression tends to obtain very small values compared to $R^{2}$ obtained in multiple regression, it can be said that an $R^{2}$ value between $0,20-0,40$ is high (Şenel \& Alatlı 2014, 41). Table 9 shows the classification results of participants with "low" and "high" academic performance after the inclusion of predictive variables in the regression model, where participants were classified according to their academic performance levels.

Table 9. Classification Results of Generated Model

\begin{tabular}{|l|l|l|l|}
\hline \multicolumn{4}{|c|}{ Academic Performance } \\
\hline & Low (0) & High (1) & Correct classification (\%) \\
\hline Low (0) & 90 & 24 & 78,90 \\
\hline High (1) & 24 & 100 & 80,60 \\
\hline Total classification & 114 & 124 & 79,80 \\
\hline
\end{tabular}


As shown in Table 9, 90 of the 114 individuals with low academic performance were correctly classified as "low" by the program and 24 participants were classified as "high" before analysis started. Similarly, 100 out of 124 participants were classified as "high", while 24 were incorrectly classified as "low". In a similar way, while 100 of the 124 participants were correctly classified as "high", 24 were incorrectly classified as "low". According to the obtained result, it was determined that the correct classification rate for the program is $79.80 \%$ after the inclusion of the model predictor variables. Finally, the results of the analysis showing the significance level of each of the predictive variables and their contribution to the regression model were evaluated. The coefficient values of the regression equation and the significance and confidence intervals of these coefficients in the model are shown in Table 10. According to this table, it can be concluded that the proposed model for the prediction of the academic performance of the students, with less than the significance (p) value of 0.05 , is found to be a meaningful contribution to the variables covered in the study.

Table 10. Values of Predictive Variables in Constructed Model

\begin{tabular}{|c|c|c|c|c|c|c|c|}
\hline & & B & S.E. & Wald & $\mathrm{df}$ & Sig. & $\operatorname{Exp}(B)$ \\
\hline \multirow[t]{11}{*}{ Step 1(a) } & Gender & ,764 & ,374 & 11,40 & 1 & ,001 & 1,282 \\
\hline & Secure & ,824 & ,455 & 23,94 & 1 & ,000 & 1,647 \\
\hline & Fearful &,- 453 & 279 & 2,647 & 1 & ,104 & 635 \\
\hline & Preoccupied &,- 266 & 310 &, 733 & 1 & ,392 &, 767 \\
\hline & Dismissing & ,198 & ,288 & ,474 & 1 & ,491 & 1,219 \\
\hline & Extraversion & ,682 & ,387 & 9,665 & 1 &, 002 & 1,331 \\
\hline & Agreeableness &, 115 &, 252 & ,209 & 1 & ,648 & 1,12 \\
\hline & Conscientiousness &, 598 & ,318 & 3,538 & 1 &, 060 &, 550 \\
\hline & Neuroticism &,- 153 & ,171 & ,807 & 1 & ,369 & ,858 \\
\hline & Openness &, 583 & ,271 & 4,628 & 1 &, 031 & 1,791 \\
\hline & Fix & $-5,852$ & 1,901 & 9,480 & 1 & ,002 &, 003 \\
\hline
\end{tabular}

With predicting variables that have a significant effect, $\beta$ values show the positive or negative direction of relation, while the coefficient's numerical value indicates the severity of the relationship. According to these, a secure attachment style shows the highest influence in this model with $(\beta=-.824, \mathrm{p}=.000)$, followed by gender variable $(\beta=-.76, \mathrm{p}=.001)$. From participants personality traits it was shown that extraversion $(\beta=.68, \mathrm{p}=.002)$ and openness $(\beta=-.58, \mathrm{p}=.031)$ variable have statistically significant influence in the proposed model. Exp (B) values, known as odds ratios recorded in the last column of the table indicate how much an increase in one unit of independent variable would result in an increase in the dependent variable. According to this, a rise of one unit in secure attachment variables will result in increase of 1, 64 points in the students' academic performance. In a similar way, when looking at personality traits, if extraversion will increase by one point it will result in a 1,33 point increase in academic performance; while a change of one unit in the openness dimension will lead to a 1,79 point difference in academic performance scores. After conducting this analysis it can be concluded that hypothesis H1a, H1e, H2a, H3 are confirmed, while hypothesis H1b, H1c, H1d, H2b, H2c, $\mathrm{H} 2 \mathrm{~d}$ were rejected.

\section{Discussion and Conclusion}

Throughout history, many psychological researchers have examined cognitive and personality traits as predictors of academic performance. Previous studies have shown that motivation, learning strategies and personality traits affect students' academic performance. This study 
examines the psychological and demographic factors that influence university students' academic performance.

In this study it was found that there is a positive relationship between secure attachment and academic performance. According to attachment theory, a secure attachment makes people feel valued and see others as useful and trustworthy. It helps them to develop a solid base of emotion, allowing them to explore and manage their environment. Compared to other attachment styles, individuals with a secure attachment score show higher learning skills, cognitive skills and academic success. Securely connected individuals develop a safe internal working model. Statistically significant positive relationships were found between a secure attachment style and academic self-efficacy (Tavakolizadeh 2015). Students with this attachment style exhibit higher levels of self-efficacy in their schools and have internal motivation to learn and achieve. According to research conducted among computer software workers and university employees, it was found that secure attachment individuals have higher job motivation and are more successful in performing their duties. Secure attachment medical students show higher clinical performance (Fletcher et al. 2016). Further research studies prove that students with secure attachment tend to have higher rates of engagement with tasks in their school/classroom when compared to insecure attachment styles (McCormick et al. 2016). Secure attachment may be considered an important factor affecting job performance and job success (Ronen \& Zuroff 2017).

The gender variable was also found to be an important predictor of performance. Soric and colleagues (2017) found in their study that gender has a significant mediator effect in explaining students' academic achievement. Many researches emphasize that girls have a higher academic achievement than boys. The rationale for this statement lies in the fact that girls are more sensitive in terms of social approval than boys. For example, it may be said that factors such as better communication between teachers and girls, modeling typical gender behaviors of teachers and parents and expressing different expectations for boys and girls, are effective to this end.

When examining the relationship between academic performance and personality traits it can be seen that openness towards development and extraversion are important predictors of academic performance. Personality is defined as the psychological qualities that contribute to the permanent and distinctive emotions, thoughts and behavioral patterns of a person.

Because of the complex nature and the differences between cultures, the most difficult defining dimension of the Big Five theory is openness (Poropat 2014). The openness dimension is often conceptualized as creative, intelligent, intellectual, and curious. Generally this dimension has two directions: one aspect reflects thinking and curiosity, while the other focuses on esthetics. Openness, sometimes called Intelligence, is the dimension mostly related to the concepts of wisdom, intelligence and reasoning, with the intellect. Its second aspect is the closest one to learning and academic performance. Openness towards development affects the willingness to learn, the level of intellectual investment in learning and subsequent academic performance. Openness is the second dimension with strongest correlation after conscientiousness. Openness towards development can be expressed as a learning approach when thinking and the curiosity of students to follow their inner interests in seeking intellectual satisfaction. If educators offer a more structured learning model to students with a low level of openness and a discovery learning model to those students who score high on this dimension, they can expect to achieve higher academic success. Extraversion is one of the key components of interpersonal behavior. Extravert individuals are characterized as sociable, talkative and lively. Extravert students learn more and reach a higher academic performance as they interact more with their teachers 
(Poropat 2014).

The results of this study provide a significant contribution to literature as it determines which factors are effective in explaining the academic achievements of university students. Its importance lies in the fact that there is only a limited number of studies that try to explain academic performance. It also provides a light to educators in determining their educational strategies.

\section{REFERENCES}

Ainsworth M., Blehar M., Waters E. \& Wall S. (1978). Patterns of Attachment: A Psychological Study of the Strange Situation. Hillsdale 1978.

Alkan N. (2007). Beş Faktör Kişilik Ölçeğinin Geçerlik ve Güvenirlik Çalışması. Yayımlanmamış Araştırma. Ankara 2007.

Barrick M. R. \& Mount M. K. (1991). "The Big Five Personality Dimensions and Job Performance: A Meta-Analysis". Personnel Psychology 44 (1991) 1-25.

Barclay K. J. (2015). "Birth order and Educational Attainment: Evidence from Fully Adopted Sibling Groups". Intelligence 48 (2015) 109-122.

Blanch A. \& Aluja A. (2013). "A Regression Tree of the Aptitudes, Personality, and Academic Performance Relationship". Personality and Individual Differences 54 (2013) 703-708.

Bonaccio S., Reeve C. L. \& Lyerly J. (2016). "Academic Entitlement: Its Personality and General Mental Ability Correlates, and Academic Consequences". Personality and Individual Differences 102 (2016) 211216.

Bonesrønninga H. \& Massih S. S. (2011). "Birth Order Effects on Young Students' Academic Achievement". The Journal of Socio-Economics 40 (2011) 824-832.

Bowlby J. (1973). Attachment and Loss: Vol. 2. Separation: Anxiety and Anger. New York 1973.

Burger J. M. (2006 $\left.{ }^{1}\right)$. Personality. Çev. İ. Deniz Erguvan-Sarığlu. İstanbul 2006.

Caprara G. V., Vecchione M., Alessandri G., Gerbino M. \& Barbaranelli C. (2011). "The Contribution of Personality Traits and Self-Efficacy Beliefs to Academic Achievement: A Longitudinal Study". British Journal of Educational Psychology 81/1 (2011) 78-96.

Ciorbeaa I. \& Pasaricaa F. (2013). "The Study of the Relationship between Personality and Academic Performance". Social and Behavioral Sciences 78 (2013) 400-404.

Conte J. M., Heffner T. S., Roesch S. C. \& Aasen B. (2017). "A Person-Centric Investigation of Personality Types, Job Performance and Attrition”. Personality and Individual Differences 104 (2017) 554-559.

Duchesne S. \& Larose S. (2007). "Adolescent Parental Attachment and Academic Motivation and Performance in Early Adolescence”. Journal of Applied Social Psychology 37 (2007) 1501-1521.

Edelstein R. S. \& Gillath O. (2008). "Avoiding Interference: Adult Attachment and Emotional Processing Biases". Personality and Social Psychology Bulletin 34/2 (2008) 171-181.

Fletcher I., McCallum R. \& Peters S. (2016). "Attachment Styles and Clinical Communication Performance in Trainee Doctors". Patient Education and Counseling 99 (2016) 1852-1857.

Friedman H. S. \& Schustack M. W. (1999). Personality: Classic Theories and Modern Research. USA 1999.

Gillath O., Bunge S., Shaver P., Wendelken C. \& Mikulincer M. (2005). "Attachment-Style Differences in the Ability to Suppress Negative Thoughts: Exploring the Neural Correlates". Neuroimage 28 (2005) 835-847.

Gillath O., Shaver P., Baek J. \& Chun D. (2008). "Genetic Correlates of Attachment Style". Personality and Social Psychology Bulletin 34 (2008) 1396-1405.

Gillath O., Giesbrecht B. \& Shaver P. R. (2009). "Attachment, Attention, and Cognitive Control: Attachment Style and Performance on General Attention Tasks". Journal of Experimental Social Psychology 45 (2009) 647-654.

Gillath O., Canterberry M. \& Atchley P. (2017). "Attachment as a Predictor of Driving Performance" 
Transportation Research Part 45 (2017) 208-217.

Griffin D. W. \& Bartholomew, K. (1994). "Models of the Self and Other: Fundamental Dimensions Underlying Measures of Adult Attachment”. Journal of Personality and Social Psychology 67/3 (1994) 430-445.

Gupta N. D. \& Simonsen M. (2016). "Academic Performance and Type of Early Childhood Care". Economics of Education Review 53 (2016) 217-229.

Harms P. D. (2011). “Adult Attachment Styles in the Workplace”. Human Resource Management Review 21 (2011) 285-296.

Hazan C. \& Shaver P. R. (1987). "Romantic Love Conceptualized as an Attachment Process". Journal of Personality and Social Psychology 52 (1987) 511-524.

Hazan C. \& Shaver P. R. (1990). "Love and Work: An Attachment-Theoretical Perspective". Journal of Personality and Social Psychology 59 (1990) 270-280.

Hertwig R., Davis J. N. \& Sulloway F. J. (2002). "Parental Investment: How an Equity Motive Can Produce Inequality”. Psychological Bulletin 128 (2002) 728-745.

Iacovou M. (2008). "Family Size, Birth Order, and Educational Attainment". Marriage and Family Review 42/3 (2008) 35-57.

Jacobsen T., Edelstein W. \& Hoffman V. (1994). "A Longitudinal Study of the Relation between Representations of Attachment in Childhood and Cognitive Functioning in Childhood and Adolescence". Developmental Psychology 30 (1994) 112-124.

Jacobsen T. \& Hoffman V. (1997). “Children's Attachment Representations: Longitudinal Relations to School Behavior and Academic Competency in Middle Childhood and Adolescence". Developmental Psychology 33 (1997) 703-710.

Kim S., Fernandez S. \& Terrier L. (2017). "Procrastination, Personality Traits, and Academic Performance: When Active and Passive Procrastination Tell a Different Story". Personality and Individual Differences 108 (2017) 154-157.

Learner D. \& Kruger L. J. (1997). “Attachment, Self-Concept, and Academic Motivation in High School Students". American Journal of Orthopsychiatry 67 (1997) 485-492.

Macht G. A. \& Nembhard D. A. (2015). "Measures and Models of Personality and Their Effects on Communication and Team Performance". International Journal of Industrial Ergonomics 49 (2015) 78-89.

Maltais C., Duchesne S., Ratelle C. F. \& Feng B. (2015). “Attachment to the Mother and Achievement Goal Orientations at the Beginning of Middle School: The Mediating Role of Academic Competence and Anxiety". Learning and Individual Differences 39 (2015) 39-48.

McCrae R. R. \& Costa P. T. (1985). "Updating Norman's Adequate Taxonomy: Intelligence and Personality Dimensions in Natural Language and in Questionnaires". Journal of Personality and Social Psychology 49 1985) 710-721.

McCrae R. R. \& John O. P. (1992). “An Introduction to the Five Factor Model and Its Applications". Journal of Personality 60 (1992) 175-215.

McCrae R. R. \& Costa P. T. Jr. (2008). "Empirical and Theoretical Status of the Five-Factor Model of Personality Traits". Eds. G. Boyle, G. Matthews \& D. H. Saklofske, The SAGE Handbook of Personality Theory and Assessment: Personality Theories and Models (2008) 273-294. Sage.

McCormick M. P., O’Connor E. E. \& Barnes S. P. (2016). “Quarterly Mother-Child Attachment Styles and Math and Reading Skills in Middle Childhood: The Mediating Role of Children's Exploration and Engagement”. Early Childhood Research Quarterly 36 (2016) 295-306.

Mikulincer M., Gillath O. \& Shaver P. R. (2002). "Activation of the Attachment System in Adulthood: Threat-Related Primes Increase the Accessibility of Mental Representations of Attachment Figures". Journal of Personality and Social Psychology 83 (2002) 881-895.

Mikulincer M. \& Shaver P. R. (2007). Attachment in Adulthood: Structure, Dynamics, and Change. New York 2007.

Moss E. \& St-Laurent D. (2001). "Attachment at School Age and Academic Performance". Developmental Psychology 37 (2001) 863-874. 
Noftle E. \& Shaver P. (2006). "Attachment Dimensions and the Big Five Personality Traits: Associations and Comparative Ability to Predict Relationship Quality". Journal of Research in Personality 40 (2006) 179-208.

Nunnally C. J. (1978). Psychometric Methods. New York 1978.

Özer E. (2013). Üniversite Öğrencilerinin Psikolojik Să̆lamlık Düzeylerinin Duygusal Zeka ve Beş Faktör Kişilik Özellikleri Açısından İncelenmesi. Yayımlanmamış Doktora Tezi. Konya Necmettin Erbakan Üniversitesi, Eğitim Bilimleri Enstitüsü, Konya 2013.

Picardi A., Caroppo E., Toni A., Bitetti D. \& Di Maria G. (2005). "Stability of Attachment-Related Anxiety and Avoidance and Their Relationships with the Five-Factor Model and the Psychobiological Model of Personality". Psychology and Psychotherapy: Theory, Research, and Practice 78 (2005) 327-345.

Price J. (2008). "Parent-Child Quality Time: Does Birth Order Matter?". Journal of Human Resources 43 (2008) 240-265.

Poropat A. E. (2014). "Other-Rated Personality and Academic Performance: Evidence and Implications". Learning and Individual Differences 34 (2014) 24-32.

Roisman G., Holland A., Fortuna K., Fraley R. C., Clausell E. \& Clarke A. (2007). "The Adult Attachment Interview and Self-Reports of Attachment Style: An Empirical Approchement". Journal of Personality and Social Psychology 92 (2007) 678-697.

Richardson M., Abraham C. \& Bond R. (2012). "Psychological Correlates of University Students' Academic Performance: A Systematic Review and Meta-Analysis". Psychological Bulletin 138/2 (2012) 353.

Ronen S. \& Zuroff D. C. (2017). "How Does Secure Attachment Affect Job Performance and Job Promotion? The Role of Social-Rank Behaviors". Journal of Vocational Behavior 100 (2017) 137-148.

Shaver P. R., Hazan C. \& Bradshaw D. (1988). "Love as Attachment: The Integration of Three Behavioral Systems". Eds. R. J. Sternberg \& M. L. Bames, The Psychology of Love (1988) 68-99. New Haven.

Shaver P. \& Brennan K. A. (1992). "Attachment Styles and the 'Big Five' Personality Traits: Their Connections with Each Other and with Romantic Relationships Outcomes". Personality and Social Psychology Bulletin 18 (1992) 536-545.

Simpson J. A. \& Rholes W. S. (Eds.). (2015). Attachment Theory and Research: New Directions and Emerging Themes. New York 2015.

Sorić I., Penezić Z. \& Burić I. (2017). "The Big Five Personality Traits, Goal Orientations, and Academic Achievement". Learning and Individual Differences 54 (2017) 126-134.

Sümer N. \& Güngör D. (1999). "Yetişkin Bağlanma Stilleri Ölçeklerinin Türk Örneklemi Üzerinde Psikometrik Değerlendirmesi ve Kültürlerarası Bir Karşllaştırma”. Türk Psikoloji Dergisi 14/13 (1999) 71106.

Sümer N., Lajunen T. \& Özkan T. (2005). "Big Five Personality Traits as the Distal Predictors of Road Accident Involvement". Ed. G. Underwood, Traffic and Transport Psychology: Theory and Application. Elsevier Science and Technology (2005) 215-227.

Şenel S. \& Alatlı B. (2014). "Lojistik Regresyon Analizinin Kullanıldığı Makaleler Üzerine Bir İnceleme". Eğitimde ve Psikolojide Ölçme ve Değerlendirme Dergisi 5/1 (2014) 35-52.

Tavakolizadeh J., Tabari J. \& Akbari A. (2015). "Academic Self-Efficacy: Predictive Role of Attachment Styles and Meta-Cognitive Skills". Social and Behavioral Sciences 171 (2015) 113-120.

Vedel A., Thomsen D. K. \& Larsen L. (2015). "Personality, Academic Majors and Performance: Revealing Complex Patterns". Personality and Individual Differences 85 (2015) 69-76.

Wihler A., Meurs J. A., Wiesmann D., Troll L. \& Blickle G. (2017). "Extraversion and Adaptive Performance: Integrating Trait Activation and Socio-Analytic Personality Theories at Work". Personality and Individual Differences 116 (2017) 133-138.

Zhou M. (2015). "Moderating Effect of Self-Determination in the Relationship between Big Five Personality and Academic Performance". Personality and Individual Differences 86 (2015) 385-389. 